\title{
Evaluation of Serum Levels of Hepatic Enzymes and Plasma Proteins between Different Types of Acute Viral Hepatitis
}

\author{
M A Zaman'1, HB Asad², M N Roy², N Hoque ${ }^{2}$, M Nasiruddin $^{3}$, \\ MBK Choudhury4 ${ }^{4}$ L Siddique ${ }^{2}$, MAM Talukder ${ }^{2}$ \\ 1D ept of Biochemistry, Ad-din Women's M edical College, D haka. \\ 2D ept of Biochemistry, Sir Salimullah Medical College, Dhaka. \\ 3D ept of Biochemistry, NICVD, D haka. \\ 4DGHS, Deputed to Dept of Pharmacy, J ahangir Nagar U niversity
}

\begin{abstract}
This cross-sectional study was carried out in 80 serologically diagnosed cases of acute viral hepatitis to assess and compare the serum hepatic enzymes \& plasma proteins between four different types $(A, B, C, E), 20$ in each group. Hepatitis $E$, hepatitis $B$ and hepatitis $C$ were more prevalent in males than that in females. The study showed that geometric mean of S.AST of all the four types differed significantly ( $F=274.94$, $p<0.001$ ). Geometric mean of S.ALT, S.AST and S.ALP in cases of HCV were significantly lower than others $(p<0.001)$. Geometric mean of S.ALT \& S.AST in cases of HEV were significantly increased than others $(p<0.001)$. But the geometric mean of S.ALP of HBV was significantly higher than others $(p<0.001)$. On the other hand though S.ALP of HAV and HEV was lower than HBV but significantly higher than HCV $(p<0.001)$. The mean \pm SD of serum albumin of HCV was decreased significantly in contrast to those of HAV and HBV $(p<0.001)$. A:G ratio of HCV was also significantly lower than other three $(p<0.001)$. It was revealed through the study that hepatic enzymes were most affected in cases of HEV but least affected in cases of HCV.
\end{abstract}

Key words : Viral Hepatitis, Hepatic Enzymes, Plasma Proteins

\section{Introduction}

Viral hepatitis is the inflammation of the liver caused by hepatitis viruses. It is defined as acute hepatitis when the inflammation resolves within six months. Viral hepatitis is known to occur throughout the world. The most common causes of acute viral hepatitis are the five unrelated hepatotropic viruses:hepatitis $A$, hepatitis $B$, hepatitis $C$, hepatitis $D$, and hepatitis $E$. Bangladesh is a small developing country in South East A sia with a population density of 830 per sq. km, virus related liver diseases are important causes of morbidity and mortality ${ }^{1}$.

HAV transmitted through faeco-oral route, is common in developing countries with very poor sanitary and hygienic conditions (part of A frica,
A sia and South Africa). HAV infection in children under five years is asymptomatic in more than $90 \%$ cases whereas symptomatic in about $70-80 \%$ adults 2 .

WHO estimates that 2000 million people have been infected by HBV worldwide per year. Of these, more than 300 million are chronically infected carriers, of whom 25 percent are at risk of serious illness and eventually leading to death from cirrhosis or hepatocellular carcinoma. According to $\mathrm{WHO}$, Bangladesh belongs to the intermediate $(4.0 \%)$ zone of HBV carrier rate and has an estimated 7.4 million carriers ${ }^{3}$. In Bangladesh HBV accounts for 35\% acute viral hepatitis ${ }^{1}$. HBsAg prevalence among apparently healthy individuals varies between 2.3 and $9.7 \% 4$. 
20 Bangladesh J M ed Biochem; 3(1)

Hepatitis C causes both acute and chronic infections and is predominantly asymptomatic. Approximately $85 \%$ of individuals with $\mathrm{HCV}$ infection develop chronic hepatitis but risk of fulminant or sub acute hepatic failure is rare. Hepatitis D virus (HDV), small defective single stranded RNA virus. It cannot replicate on its own and it is infective only in the presence of HBV.

Hepatitis E virus (HEV) is a nonenveloped single stranded RNA virus ${ }^{5}$. HEV causes both sporadic and epidemic acute hepatitis. Hepatitis $E$ is mainly a disease of young adults. It may be complicated by fulminant and sub-acute hepatic failure. Hepatitis $E$ is transmitted through faecally contaminated drinking water.

Viral causes of hepatitis are indistinguishable from one another. Because clinical signs are of little or no help for identifying various causes of viral hepatitis. This can be a problem because appropriate management often depends on the specific virus involved. The ability to distinguish the viruses that cause the hepatitis is the result of serological test for specific viral marker. They are difficult to identify, costly and not possible for the major portion of the people of our country. Biochemical changes that happen in viral hepatitis are easy to identify, cheaper and can be evaluated even in remote corners of Bangladesh 6 .

This study was carried out to find out any definite and distinguishable changes in biochemical profile regarding viral hepatitis. If so that will be of an immense help for the clinicians to differentiate the cause of the viral hepatitis without detecting the costly viral markers.

\section{Materials and Methods}

This cross-sectional study was carried out from January 2006 to December 2006 in Department of Biochemistry, Sir Salimullah M edical College and Hospital, Dhaka. According to the predesigned exclusion $\&$ inclusion criteria 80 diagnosed viral hepatitis cases were selected by taking history \& laboratory investigations.
M A Zaman, HB A sad, MN Roy et al. Blood samples were collected with all aseptic measures from antecubital vein by disposable syringes. Serum was separated by centrifugation at 3000-4000 rpm for 3-5 minutes. Estimations of serum bilirubin, $A L T, A S T, A L P$, total protein and albumin were carried out by colorimetric method. Serum globulin and AG ratio were calculated.

The continuous variables were expressed in mean $\pm S D$ and other variables that did not show normal distribution were expressed as geometric mean $\pm S D$. Test for significance between four groups were done by ANOVA and Boneferroni. A p value of $<0.05$ was accepted as level of significance. The data was analyzed by using statistical software SPSS-10.0 version for Windows.

Results

Geometric mean $\pm S D(U / L)$ of $A L T$ were $807.23 \pm 1.19, \quad 866.16 \pm 1.35, \quad 64.3 \pm 1.79$ and $1900.20 \pm 1.44$ in hepatitis A, B, C and E respectively. The geometric mean $\pm S D(U / L)$ of serum AST were $239.77 \pm 1.23,540.13 \pm 1.53$, $53.3 \pm 1.56$ and $1175.98 \pm 1.342$ in the same sequence as above. Serum ALP showed its geometric mean $\pm S D(U / L)$ in hepatitis $A, B, C$ \& $E$ as $167.53 \pm 1.32,353.43 \pm 1.30,87.56 \pm 1.37$ and $192.89 \pm 1.23$ respectively. M ean \pm SD $(\mathrm{g} / \mathrm{dl})$ of serum total protein were $6.95 \pm 0.36$, $6.94 \pm 0.37,7.3 \pm 0.55$ and $6.8 \pm 0.47$ in hepatitis $A, B, C$ and $E$ sequentially. Serum albumin had its mean $\pm S D(g / d l)$ in hepatitis $A, B, C$ and $E$ as $3.7 \pm 0.56,3.8 \pm 0.73,3.16 \pm 0.52$ and $3.6 \pm 0.49$ respectively. Serum globulin had its mean $\pm S D$ $(\mathrm{g} / \mathrm{dl})$ as $3.1 \pm 0.21,4.1 \pm 0.83,3.1 \pm 0.53$ and $3.1 \pm 0.48$ hepatitis $A, B, C$ and $E$ respectively. $M$ ean $\pm S D$ of $A: G$ ratio of hepatitis $A B, C$ and $E$ were $1.23 \pm 0.16,1.35 \pm 0.54,0.79 \pm 0.23$ and1.20 \pm 0.25 respectively. In ANOVA (Table 1) we found S.ALT, S.AST were significantly $(P<0.001, F=289.88)$ higher in HEV than HAV, HBV \& HCV.The same table showed significantly lower value of above parameters in HCV. On the other hand, S.ALP showed significantly higher $(p<0.001, F=91.38)$ value in HBV than other three groups. Multiple 
comparison by Boneferroni of serum enzymes level showed (Table II) significant difference between $\mathrm{HAV} \& \mathrm{HBV}$ regarding $\mathrm{S}$.AST $(p<0.001)$ and S.ALT $(p<0.001)$. Significant differences were seen in all three enzyme levels $(p<0.001)$ between HAV and HCV. Same pattern was also seen between $\mathrm{HBV} \& \mathrm{HCV}$, HBV \& HEV, HCV and HEV.Only HAV \& HEV showed significant differences $(P<0.001)$ in cases of S.AST, S.ALT. In respect of serum total protein no significant differences were observed among various groups except in between $\mathrm{HAV}$ vS $\mathrm{HCV}$ and $\mathrm{HCV}$ vs $\operatorname{HEV}(p<0.001) \quad(\mathrm{Fig.1} \&$ Table III). Conversely, mean value of S.albumin of HCV differed significantly in between different groups ( $p<0.001, F=8.3$ ) (Fig. 2). Multiple comparison by Boneferroni showed that serum albumin of $\mathrm{HCV}$ was decreased significantly than HAV and HBV $(p<0.001)$. A:G ratio of $\mathrm{HCV}$ was also reduced in contrast to those of other three groups. However, there is no significant difference between HAV vs HBV, $H A V$ VS HEV and HBV VS HEV in respect of serum total protein, serum albumin and serum globulin.

Table I: Serum ALT, AST, ALP in study groups

\begin{tabular}{|c|c|c|c|c|c|c|}
\hline \multirow[t]{2}{*}{ Parameters } & HAV & HBV & $\mathrm{HCV}$ & HEV & F & \\
\hline & $N=20$ & $N=20$ & $N=20$ & $N=20$ & Value & Value \\
\hline $\begin{array}{l}\text { S. ALT } \\
\text { (G.mean } \pm S D)\end{array}$ & 807.23 & 866.16 & 64.3 & 1900.2 & 289.88 & $<0.001$ \\
\hline U/L & \pm 1.19 & \pm 1.35 & \pm 1.79 & \pm 1.44 & & \\
\hline $\begin{array}{l}\text { S. AST } \\
\text { (G.mean } \pm S D)\end{array}$ & 239.23 & 540.13 & 53.3 & 1175.98 & 274.94 & $<0.001$ \\
\hline $\mathrm{U} / \mathrm{L}$ & \pm 1.23 & \pm 1.53 & \pm 1.56 & \pm 1.34 & & \\
\hline $\begin{array}{l}\text { S. ALP } \\
\text { (G.mean } \pm S D)\end{array}$ & 167.53 & 353.56 & 87.56 & 192.89 & 91.38 & $<0.001$ \\
\hline U/L & \pm 1.32 & \pm 1.3 & \pm 1.37 & \pm 1.23 & & \\
\hline
\end{tabular}

Table II: Multiple comparisons by Boneferroni of hepatic enzymes

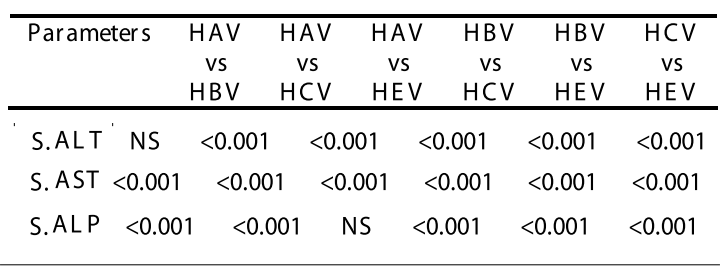

Figure I: Serum Total Protein (g/dl) in different study groups

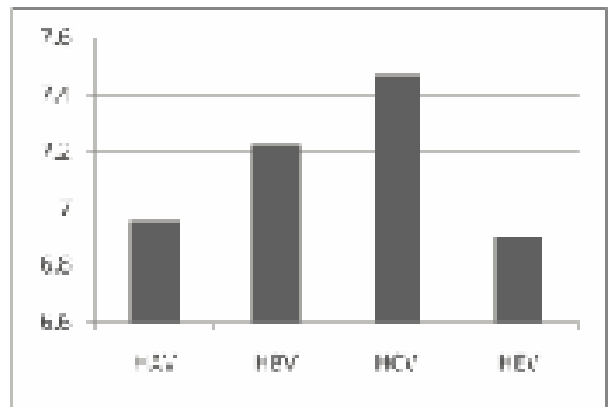

Figure 2: Serum A lbumin $(\mathrm{g} / \mathrm{dl})$ in different study groups

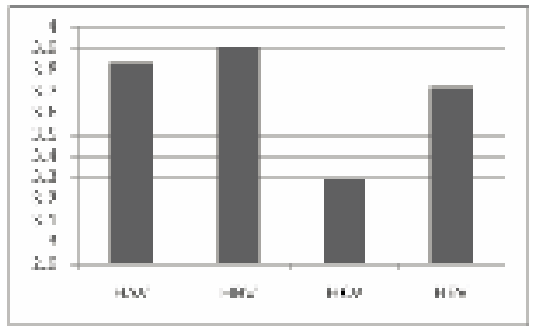

Table III: Multiple comparisons by Boneferroni of hepatic proteins.

\begin{tabular}{lcccccc}
\hline Parameters & $\begin{array}{c}\text { HAV } \\
\text { vs HBV }\end{array}$ & $\begin{array}{c}\text { HAV } \\
\text { vSHCV }\end{array}$ & $\begin{array}{c}\text { HAV } \\
\text { vs HEV }\end{array}$ & $\begin{array}{c}\text { HBV } \\
\text { vs HCV }\end{array}$ & $\begin{array}{c}\text { HBV } \\
\text { vs HEV }\end{array}$ & $\begin{array}{c}\text { HCV } \\
\text { vs HEV }\end{array}$ \\
\hline S. ALT & NS & $<0.001$ & $<0.001$ & $<0.001$ & $<0.001$ & $<0.001$ \\
S. AST & $<0.001$ & $<0.001$ & $<0.001$ & $<0.001<0.001$ & $<0.001$ \\
S. ALP & $<0.001$ & $<0.001$ & NS & $<0.001<0.001$ & $<0.001$ \\
\hline
\end{tabular}

\section{Discussion}

In this cross-sectional study an attempt was made to evaluate biochemical parameters of different virulent hepatitis viruses in our population. It showed that serum level of ALT was high in all patients of our study groups but highest in case of hepatitis $E$ followed by hepatitis $B \&$ hepatitis $A$, lowest in case of hepatitis C. S. A ST followed the same pattern of S. ALT but to a lesser extent. Serum ALP was increased in hepatitis $B$ and was within normal limit in other groups. So the above study showed that geometric mean of S.ALT, S.AST and S.ALP in cases of HCV were significantly 
lower than others. Similar studies were also done in our country, where results were almost consistent to this study 7,8 . Also the geometric mean of $S$. ALT of HBV was significantly higher than others. Moreover S. ALP of HAV and HEV was lower than HBV but significantly higher than HCV. Similar result was found in other studies abroad 9 . In respect to serum total protein no significant differences were observed among the groups, though the levels were low in other studies. Serum albumin of HCV was significantly decreased than HAV and HBV. As hepatitis $C$ is chronic in nature decreased value of serum albumin is consistent with other study ${ }^{10}$. A:G ratio of HCV were significantly lower than other three groups ${ }^{10}$. Thus it was revealed through the study that biochemical parameters were mostly affected in HEV. This may happen as HEV is self-limiting and does not progress to chronic disease. On the other hand, hepatic enzymes were least affected in HCV than others except that of serum albumin. These findings support that HCV may have a serious outcome of the disease process as it may lead to chronic hepatitis.

In conclusion, the present study shows that biochemical parameters are mostly affected in hepatitis $\mathrm{E}$ creating a panic of devastating illness whereas relatively silent HCV, though affected least biochemically, shows a vindictive outcome of the disease process.

\section{References}

1. K han M, A hmed N. Seroepidemiology of HBV and HCV in Bangladesh. J Int Hepatol Comms 1996; 5:1-2.

2. Ledhar WM, Lemon SM, Kirkpatrick JW. Frequency of illness associated with epidemic hepatitis $A$ virus infection in adults. J Epidemiol 1985;122: 226-233.

3. Kane M. Global plan of action for Hepatitis B Immunization: Global Program for Vaccine and Immunization. Expanded Program on Immunization. W orld Health Organization, Geneva.1994.

4. Rumi MA, Siddiqui MA, Azam MG. Prevalence of infectious diseases and drug abuse among Bangladeshi workers. SEA J Trop Med Public Health 2000;31: 571-4.

5. Tam AW, Smith MM, Guerra ME, Huang CC, Bradley DW, et al. Hepatitis E virus (HEV): $M$ olecular cloning and sequencing of full length viral genome. J V irol 1991; 185: 120-131.

6. A ra M . Enzymatic changes between acute hepatitis $B$ and acute hepatitis E-A comparative study. FCPS dissertation, BCPS 2002.

7. Hasan SM M. Value of liver function test in acute and chronic liver diseases. FCPS Dissertation, BCPS 1995.

8. Hossain Z, Das B,H ussain SA. V irological cause of hepatitis $A$ virus, as determined by real time RTPCR: correlation with biochemical immunological and genotype profiles. WJ Gastroenterol 2006; 29:4683-8.

9. Sainokami S, A be K, Ishikewa K. Influence of hepatitis A virus on disease severity and its relationship with clinical manifestation in patients with hepatitis A.J Gastroenterol Hepatol 2005; 8:1165-75.

10. Wahib AA, Nasr MS, Mongoud AM. The liver profile in patients with hepatitis $C$ virus. J Egypt Soc 2006; 36: 465-79 